\title{
Boas Notícias e... Muito Trabalho!!!
}

$\Delta$ Revista Brasileira de Reumatologia foi finalmente incluída na coleção SciELO Brasil! nossa sociedade. Foi o resultado de um trabalho conjunto e árduo de todos nós, autores, revisores e editores. Envolveu aprimoramento, tanto na área científica como gráfica, modificações no corpo editorial e formatação. Exigiu participação e colaboração sem perspectivas de retorno imediato, decisões difíceis, sacrifício e altruísmo e não há como agradecer o suficiente a todos os envolvidos neste processo.
Entretanto, a inclusão da RBR nesta base de dados foi apenas o primeiro passo. A sua manutenção na coleção tão ou mais difícil que a sua inclusão - implicará em dedicação e esforço ainda maiores de todos os profissionais envolvidos nesse trabalho. Confiantes na colaboração e participação cada vez maior dos colegas, nossa intenção continua sendo a de buscar a excelência científica e gráfica, corrigindo falhas e revendo decisões e posicionamentos, suscetíveis a opiniões e críticas como parte de um processo de contínuo aprimoramento.

IÊDA M. M. LAURINDO Editora
BIREME - Centro Latino-Americano e do Caribe de Informação em Ciências da Saúde Organizaçōo Pan-Americana da Saúde

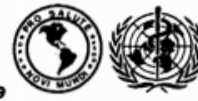

Rua Botucatu, 862 - Vila Clementino - CEP 04023-901 - Sao Paulo - SP - Brasil - Tel.: 55-11-5576-9800 - Fax 55-11-5575-8868 http://mww.bireme.br

São Paulo, 5 de julho de 2004

Prezado Editor,

Temos o prazer de comunicar que o Comitê Consultivo SciELO Brasil, em reunião realizada no dia 29 de junho de 2004, concedeu parecer favorável ao ingresso da Revista Brasileira de Reumatologia na coleção SciELO Brasil.

A Unidade SciELO entrará em contato com V.Sa. nos próximos dias para envio de informações e maiores detalhes a respeito dos procedimentos para o ingresso da revista na coleção.

Atenciosamente,

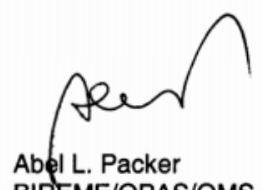

BIREME/OPAS/OMS, Diretor

Coordenador Operacional, SciELO
Ao lado, reprodução da comunicação oficial enviada pela BIREME/OPAS/ OMS à SBR, em 5/7/2004. Na seção Noticiário, reprodução fiel da página do site institucional do SciELO informando a inclusão incondicional da RBR como novo periódico na coleção SciELO Brasil. 